DOI: $10.15193 /$ zntj/2021/127/377

\author{
JOANNA BUCKA-KOLENDO, BARBARA SOKOLOWSKA
}

\title{
PORÓWNANIE METOD IDENTYFIKACJI BAKTERII LACTOBACILLUS
}

\begin{abstract}
Streszczenie
Szerokie zastosowanie bakterii kwasu mlekowego (LAB) w różnych gałęziach przemysłu spożywczego, w biotechnologii i w medycynie powoduje, że właściwa identyfikacja i ocena ich zróżnicowania wewnątrzgatunkowego jest bardzo istotna. Dobór odpowiednich technik molekularnych analizy powinien uwzględniać dużą dokładność, powtarzalność i typowalność metody.

Celem pracy była ocena możliwości różnicowania 12 szczepów Lactobacillus przy użyciu metod powszechnie stosowanych w laboratoriach: sekwencjonowania genu $16 \mathrm{~S}$ rDNA, genu pheS oraz MALDITOF MS. Na podstawie otrzymanych wyników analiz stwierdzono, że gen pheS w badanych szczepach charakteryzował się wysokim poziomem homologii (98 \%) i niską siłą dyskryminacyjną. W dwóch niezależnych analizach MALDI-TOF MS uzyskano taki sam wynik dla 10 szczepów: siedmiu - L. brevis (DSM $6235,102,103,489,863,975,3 / 16 / 1)$, dwóch - L. plantarum $(1178,133)$ i jednego - L. curvatus 557. Po przeprowadzeniu analizy sekwencjonowania genu $16 \mathrm{~S}$ rDNA wyniki potwierdziły się natomiast tylko w odniesieniu do pięciu szczepów (DSM 6235, 3/16/1 i 489) z dwunastu przebadanych. Porównanie wyników było podstawą do wnioskowania, że dla wybranych szczepów LAB największą wartość różnicującą miała analiza bazująca na sekwencjonowaniu genu $16 \mathrm{~S}$ rDNA.
\end{abstract}

Słowa kluczowe: bakterie kwasu mlekowego, LAB, gen 16S rDNA, gen pheS, MALDI-TOF MS

\section{Wprowadzenie}

Bakterie kwasu mlekowego są grupą drobnoustrojów o bardzo dużym znaczeniu ekonomicznym z uwagi na ich szerokie zastosowanie w przemyśle spożywczym (kultury starterowe i kultury ochronne) oraz w medycynie i biotechnologii (probiotyki). Zastosowanie odpowiednich technik umożliwiających precyzyjne, szybkie i jednocześnie wydajne ekonomicznie analizy jest bardzo ważne i stanowi często istotę zróżnicowania bakterii i w dużej mierze decyduje o uzyskanym wyniku. Najczęściej stosowanymi metodami identyfikacji gatunków LAB są metody bazujące na genomice ( $16 \mathrm{~S}$, phes, RAPD, rep-PCR, MLST, Real Time-PCR, DGGE/TGGE) i proteomice

Mgr inż. J. Bucka-Kolendo, dr hab. inż. Barbara Sokołowska, prof. IBPRS, Zakład Mikrobiologii, Instytut Biotechnologii Przemystu Rolno-Spożywczego im. Prof. W. Dąbrowskiego - Państwowy Instytut Badawczy,ul.Rakowiecka 36,02-532 Warszawa.Kontakt:joanna.bucka@ibprs.pl 
(MALDI-TOF MS, 2-DE) [1, 2, 3, 7, 11, 13, 14]. Dokonując wyboru techniki identyfikacji LAB, należy mieć na uwadze trzy kryteria: metoda musi charakteryzować się wystarczająco czułym potencjałem różnicującym, powtarzalnością oraz typowalnością, czyli możliwością zidentyfikowania na poziomie rodzaju, gatunku, a nawet szczepu. Powinna być również szybka i ekonomicznie opłacalna [14]. Przy wyborze metod związanych z genami konserwatywnymi trzeba uwzględniać takie czynniki, jak długość analizowanego odcinka genu oraz siła dyskryminująca genu, jak również to, że różne geny mogą dostarczać innych wyników filogenetycznych przypisujących szczepy do innego sąsiedztwa. Przez wiele lat analiza sekwencji genu $16 S$ rDNA była referencyjnym wyznacznikiem $\mathrm{w}$ określaniu filogenetycznego pokrewieństwa bakterii LAB. Stwierdzono jednak, że w przypadku blisko spokrewnionych gatunków LAB metoda ta ma zbyt małą rozdzielczość, a gen kodujący podjednostkę $16 S$ rRNA może wykazywać niewielki stopień polimorfizmu. Ponadto wysoki stopień zróżnicowania fenotypowego i genotypowego oraz zawartość par zasad G+C w zakresie $32 \div 54 \%$ może nastręczać problemów w ich identyfikacji [8]. Z tego powodu poszukiwano innych genów konserwatywnych, które mogłyby posłużyć jako wiarygodne narzędzie różnicujące o dużej czułości. Taki gen powinien charakteryzować się powszechnością występowania w genomie bakteryjnym i powinien zawierać w sobie swoisty, zmienny region, który pozwoli na jednoznaczne zróżnicowanie gatunków/podgatunków [12].

Jedną z alternatyw sekwencjonowania genu $16 S$ jest analiza genu pheS, kodującego podjednostkę $\alpha$-syntazy fenyloalanylo-tRNA (Phe-tRNA). Analiza sekwencji genu pheS uznawana jest za wiarygodną metodę dyskryminującą $[4,8,10]$ i jest obecnie powszechnie stosowanym narzędziem do identyfikacji bakterii LAB.

Pomimo dużych możliwości analizy genów konserwatywnych taksonomia tego rodzaju nie daje odpowiedzi na pytania dotyczące korelacji filogenetyki z właściwościami fizjologicznymi lub ekotypem [5]. Wprowadzane są dodatkowe techniki chemotaksonomiczne, jak MALDI-TOF MS (ang. Matrix-Assisted Laser Desorption/Ionization Time of Flight Mass Spectrometry), analizujące białka rybosomalne. W ostatnich latach nastąpił rozwój identyfikacji mikroorganizmów techniką MALDITOF MS, głównie pochodzenia klinicznego, ale również występujących w sektorze spożywczym. Metoda polegająca na analizie „odcisku palca” białek rybosomalnych, charakterystycznych dla danej rodziny, rodzaju, gatunku, a nawet dla poszczególnych szczepów, umożliwia identyfikację profili widm masowych badanych szczepów poprzez porównanie ich z biblioteką zawierającą referencyjne widma odniesienia. W odróżnieniu od technik genomowych, w których analizowane sekwencje są przyrównywane w ciągle rozbudowywanej i aktualizowanej, światowej bazie danych NCBI BLAST (ang. Basic Local Alignment Search Tool), w technice MALDI-TOF MS identyfikacja mikroorganizmów odbywa się przy użyciu wewnętrznych baz przynależnych do danego urządzenia i ewentualnie rozbudowywanych o nowe profile widm maso- 
wych na potrzeby danego laboratorium. Ograniczenia w identyfikacji MALDI-TOF MS blisko spokrewnionych gatunków, jak w przypadku LAB, mogą wynikać z braku referencyjnych widm masowych $\mathrm{w}$ bazie danych przynależnej do aparatu, $\mathrm{z}$ błędów technicznych powstałych podczas przygotowania próbki do analizy lub z różnych warunków hodowlanych, które mogą oddziaływać na wynik analizy [1].Takie ograniczenia mogą stanowić dużą przeszkodę we właściwej identyfikacji mikroorganizmów, szczególnie nowych, niewystępujących w danej bazie danych.

Celem pracy była ocena możliwości różnicowania 12 szczepów Lactobacillus przy użyciu metod powszechnie stosowanych w laboratoriach: sekwencjonowania genu $16 S$ rDNA, genu pheS oraz MALDI-TOF MS.

\section{Material i metody badań}

Badaniom poddano 12 szczepów Lactobacillus wyizolowanych z żywności, w tym jeden szczep pochodzący z kolekcji DSMZ - tab. 1. Zgodnie z nową nomenklaturą [15] bakterie kwasu mlekowego zreklasyfikowano na podstawie najnowszych danych genetycznych i filogenetycznych.

Tabela 1. Taksonomia analizowanych szczepów LAB według $16 \mathrm{~S}$ rDNA i nowej nomenklatury Table 1. Taxonomy of analysed LAB strains according to $16 \mathrm{~S}$ rDNA and new nomenclature

\begin{tabular}{||c|c|c|c||}
\hline $\begin{array}{c}\text { Szczep } \\
\text { Strain }\end{array}$ & Źródło / Source & $\begin{array}{c}\text { Identyfikacja wg 16S rDNA } \\
16 \text { rDNA identification }\end{array}$ & $\begin{array}{c}\text { Nowa nomenklatura } \\
\text { New nomenclature }\end{array}$ \\
\hline 1178 & Chleb / Bread & Lactobacillus plantarum & Lactiplantibacillus plantarum \\
\hline 975 & $\begin{array}{c}\text { Sok pomidorowy } \\
\text { Tomato juice }\end{array}$ & Lactobacillus rhamnosus & Lacticaseibacillus rhamnosus \\
\hline 863 & $\begin{array}{c}\text { Sok pomidorowy } \\
\text { Tomato juice }\end{array}$ & Lactobacillus plantarum & Lactiplantibacillus plantarum \\
\hline DSM 6235 & Piwo / Beer & Lactobacillus brevis & Levitlactobacillus brevis \\
\hline 102 & Piwo / Beer & Lactobacillus backii & Loigolactobacillus backii \\
\hline 103 & Piwo / Beer & Lactobacillus backii & Loigolactobacillus backii \\
\hline 133 & Probiotyk / Probiotic & Lactobacillus rhamnosus & Lacticaseibacillus rhamnosus \\
\hline $3 / 16 / 1$ & Piwo / Beer & Lactobacillus brevis & Levitlactobacillus brevis \\
\hline 432 & $\begin{array}{c}\text { Sok z kiszonych ogórków } \\
\text { Saurkraft juice }\end{array}$ & Lactobacillus curvatus & Latilactobacillus curvatus \\
\hline 489 & Piwo / Beer & Lactobacillus brevis & Levitlactobacillus brevis \\
\hline 557 & Piwo / Beer & Lactobacillus brevis & Levitlactobacillus brevis \\
\hline 738 & Piwo / Beer & Lactobacillus rossiae & Furfurilactobacillus rossiae \\
\hline
\end{tabular}

Bakterie kwasu mlekowego izolowano z produktów spożywczych zgodnie z procedurą PN-ISO 15214:2002 [9]. W zależności od potrzeb LAB posiewano na pożywkę MRS agar (Lactobacillus Agar według DeMan, Rogosa i Sharpe, Merck KGaA, Niemcy) lub do pożywki MRS bulion (Merck KGaA, Niemcy) i inkubowano w temp. $30^{\circ} \mathrm{C}$ przez $72 \mathrm{~h} \mathrm{w}$ warunkach anaerobowych. 
Zastosowano trzy rodzaje analiz (sekwencjonowanie genu $16 S$, pheS oraz MALDI-TOF MS) w celu porównania możliwości różnicujących każdej z metod.

Do izolacji DNA z 18-godzinnych hodowli płynnych badanych szczepów używano zestawu ExtractMe DNA Bacteria Kit (Blirt, Gdańsk, Polska) zgodnie z instrukcją producenta. Sekwencjonowanie genu $16 S$ rDNA prowadzono z wykorzystaniem primerów 16SF: 5'-AGACTTTGATCCTGGCTCAG-3' i 16SR: 5'-ACGGCTACCTTG TTACGACT-3' amplifikujących prawie całą sekwencję genu o długości ok. 1500 bp. Warunki przeprowadzonej reakcji opisano w pracy Buckiej-Kolendo i wsp. [3].

Analizę genu pheS prowadzono z wykorzystaniem primerów pheS-21-F: 5'CAYCCNGCHCGYGAYATGC-3' i pheS-22-R: 5'-GGRTGRACCATVCCNGCHCC -3 ' w warunkach podanych przez Nasera i wsp. [7].

$\mathrm{Na}$ podstawie wyników sekwencjonowania genu $16 \mathrm{~S}$ rDNA i pheS badanych szczepów Lactobacillus przeprowadzano analizę filogenetyczną z zastosowaniem algorytmu CLUSTAL W. Przy użyciu programu MEGAX [6] dokonywano alignmentu sekwencji i konstruowano na ich podstawie drzewa z wykorzystaniem analizy Neighbor-Joining z odległościami obliczonymi metodą największej wiarygodności. Odległości ewolucyjne obliczano przy użyciu metody największej złożonej wiarygodności. Zostały one podane $\mathrm{w}$ jednostkach liczby podstawień zasad przypadających na miejsce. Ostateczny zbiór danych zawierał łącznie 1480 pozycji dla genu $16 S$ DNA oraz 390 pozycji dla pheS. Różnorodność nukleotydów badanych sekwencji była odpowiednio na poziomie $\pi=0,86$ i 0,16 .

Analizę MALDI-TOF MS wykonywano przy użyciu dwóch niezależnych aparatów Biotyper (Bruker Daltonik GmbH, Niemcy), każdy z własną bazą danych. Do badań stosowano 18-godzinne hodowle $\mathrm{LAB} \mathrm{w}$ warunkach przedstawionych przez Bucką-Kolendo i wsp. [3]. W obu przypadkach jako matrycę stosowano HCCA ( $\alpha$-cyano-4-hydroxycinnamic acid). Analizę widm masowych przeprowadzona w programie BioNumerics 7.6.3 (Applied Maths). Wykonano po trzy powtórzenia widm wszystkich badanych szczepów.

Hierarchiczną analizę skupień widm MALDI-TOF MS prowadzono na podstawie macierzy podobieństw obliczonej z zastosowaniem współczynnika Pearsona. Profile widm masowych tworzono $\mathrm{w}$ odniesieniu do ich sygnałów i intensywności otrzymanych pików. Alignment i grupowanie prowadzono z tolerancją liniową $300 \mathrm{ppm}$ i stałą tolerancją 0,5. Wyniki uzyskane techniką MALDI-TOF MS poddano analizie wielowymiarowego skalowania profili widm masowych (MDS - Multi Dimensional Scaling), która jest uważana za alternatywę analizy czynnikowej.

\section{Wyniki i dyskusja}

Na podstawie badań filogenetycznych, mających na celu ustalenie wzajemnego pokrewieństwa szczepów Lactobacillus, przeprowadzonych metodą analizy sekwencji 
genów $16 S$ i pheS, wykazano, że gen $16 S$ miał większy potencjał różnicujący. Podobieństwo analizowanych sekwencji genu $16 S$ rDNA (rys. 1) było na poziomie $89 \%$ dla 10 szczepów, homologia 2 szczepów (L. backii 103 i L. brevis 557) stanowiła mniej niż $79 \%$ w stosunku do pozostałych i zostały one ujęte w oddzielny klaster. Otrzymana różnorodność nukleotydowa sekwencji była na poziomie $\pi=0,86$. Wyniki nie korelowały z wynikami identyfikacji bakterii bazującej na sekwencjonowaniu genu $16 \mathrm{~S}$ rDNA.

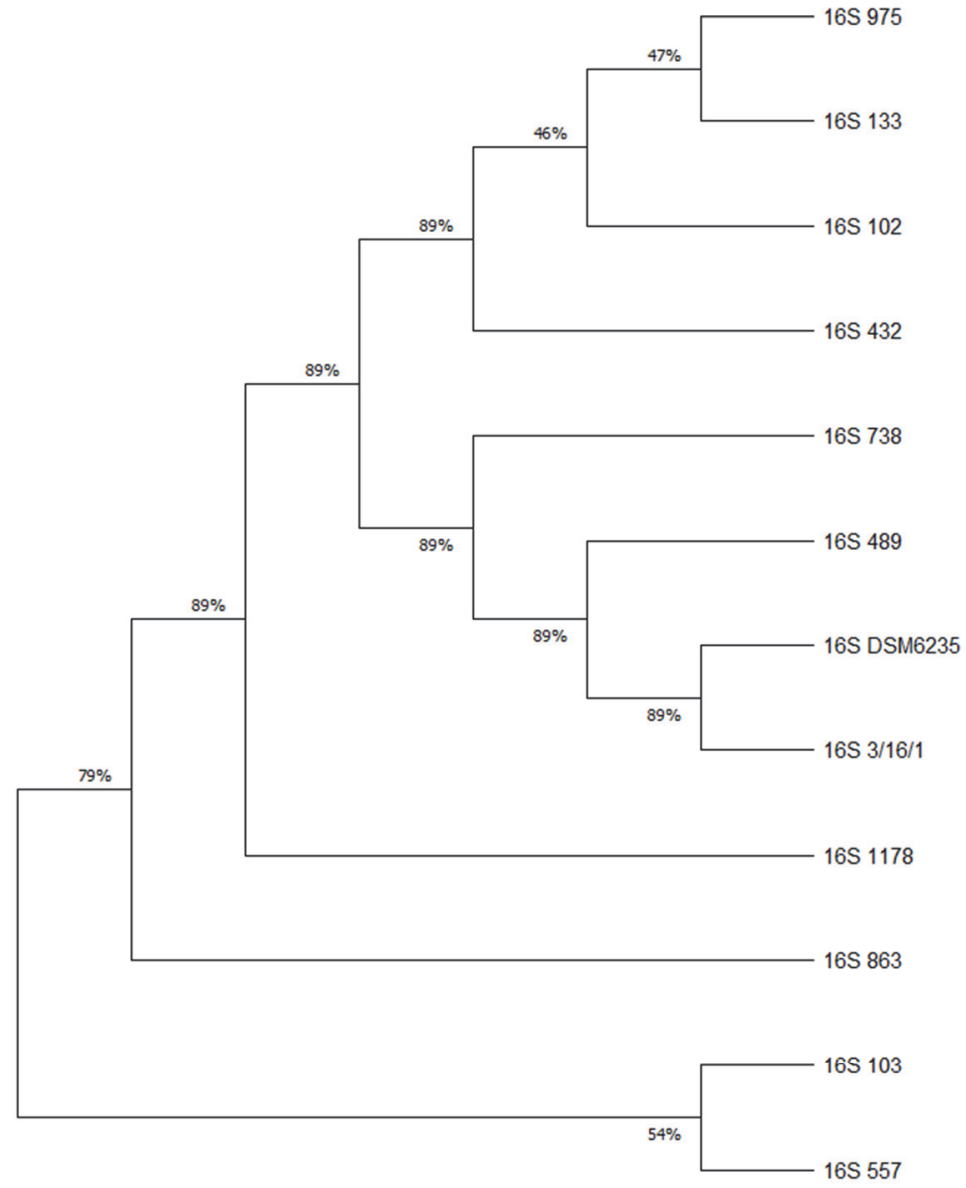

Rys. 1. Drzewo filogenetyczne skonstruowane na podstawie analizy sekwencji geniu 165 rDNA przedstawiające relacje pokrewieństwa badanych szczepów (suma długości gałęzi $=3,25666995$ )

Fig. 1. Phylogenetic tree build on the basis of sequence analysis of the 16S rDNA gene and representing evolutionary relationships of taxa tested (total of branch lengths $=3.25666995$ ) 
Drzewo filogenetyczne sekwencji genu pheS (rys. 2) podzielono na dwa klastry. Jeden klaster zawierał 8 szczepów z homologią na poziomie $90 \div 98 \%$, a drugi - z 2 szczepami: 557 i 432, których podobieństwo wynosiło poniżej $90 \%$. W przypadku 2 szczepów: 102 i 103 nie udało się otrzymać sekwencji genu pheS. Różnorodność nukleotydowa $\pi$ była na poziomie 0,16 . Uzyskane wyniki korelują z wynikami identyfikacji bakterii na podstawie sekwencji genu pheS, w której 8 szczepów (DSM 6235, $1178,975,863,738,489,133,3 / 16 / 1)$ scharakteryzowano jako L. plantarum, a 2 szczepy (557 i 432) - jako L. brevis.

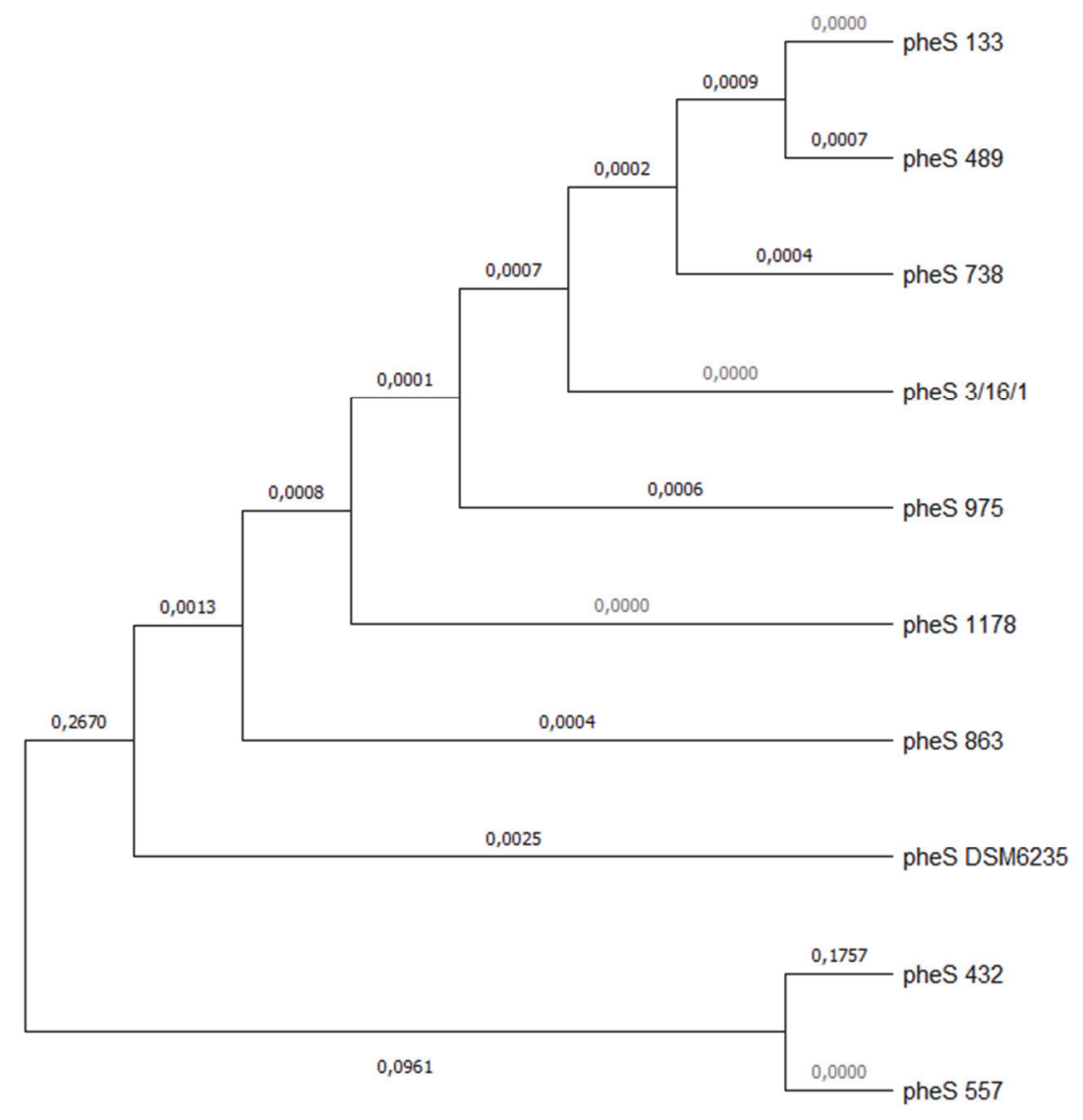

Rys. 2. Drzewo filogenetyczne skonstruowane na podstawie analizy sekwencji genu pheS przedstawiające relacje pokrewieństwa badanych szczepów (suma długości gałęzi $=0,54758904$ )

Fig. 2. Phylogenetic tree build on the basis of sequence analysis of the pheS gene and representing evolutionary relationships of taxa tested (total of branch lengths $=0.54758904$ ) 
W celach porównawczych stopnia identyfikacji techniką MALDI-TOF MS z analizą sekwencji $16 S$ rDNA i genu pheS wykonano dendrogram profili widm masowych (rys. 3). Analizę przeprowadzono metodą UPGMA. W analizie profili widm masowych (MSP) względną odległość między odkształceniami przedstawia się w jednostkach arbitralnych, gdzie 100 oznacza całkowite podobieństwo, a 0 oznacza minimalne podobieństwo.

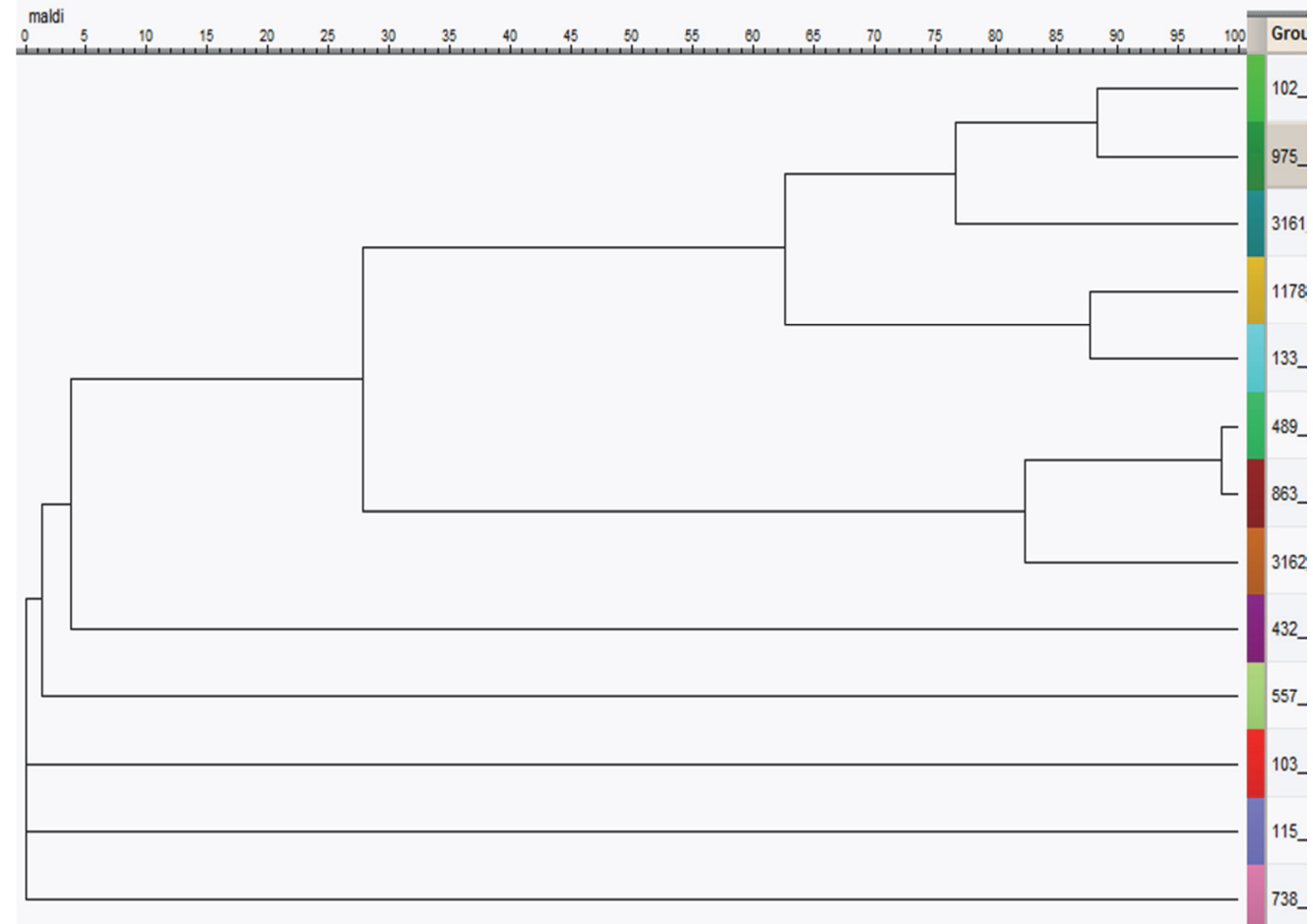

Rys. 3. Dendrogram skupień widm MALDI-TOF MS badanych szczepów LAB (barwy odpowiadają szczepom)

Fig. 3. Cluster dendrogram of MALDI-TOF MS spectra of LAB strains tested (colours represent strains)

W wyniku rozmieszczenia badanych szczepów jako punktów w przestrzeni n-wymiarowej zaobserwowano rozłożenie podobieństw i różnic pomiędzy badanymi szczepami LAB (rys. 4). Rozłożenie korelowało z hierarchiczną analizą skupień widm masowych. 


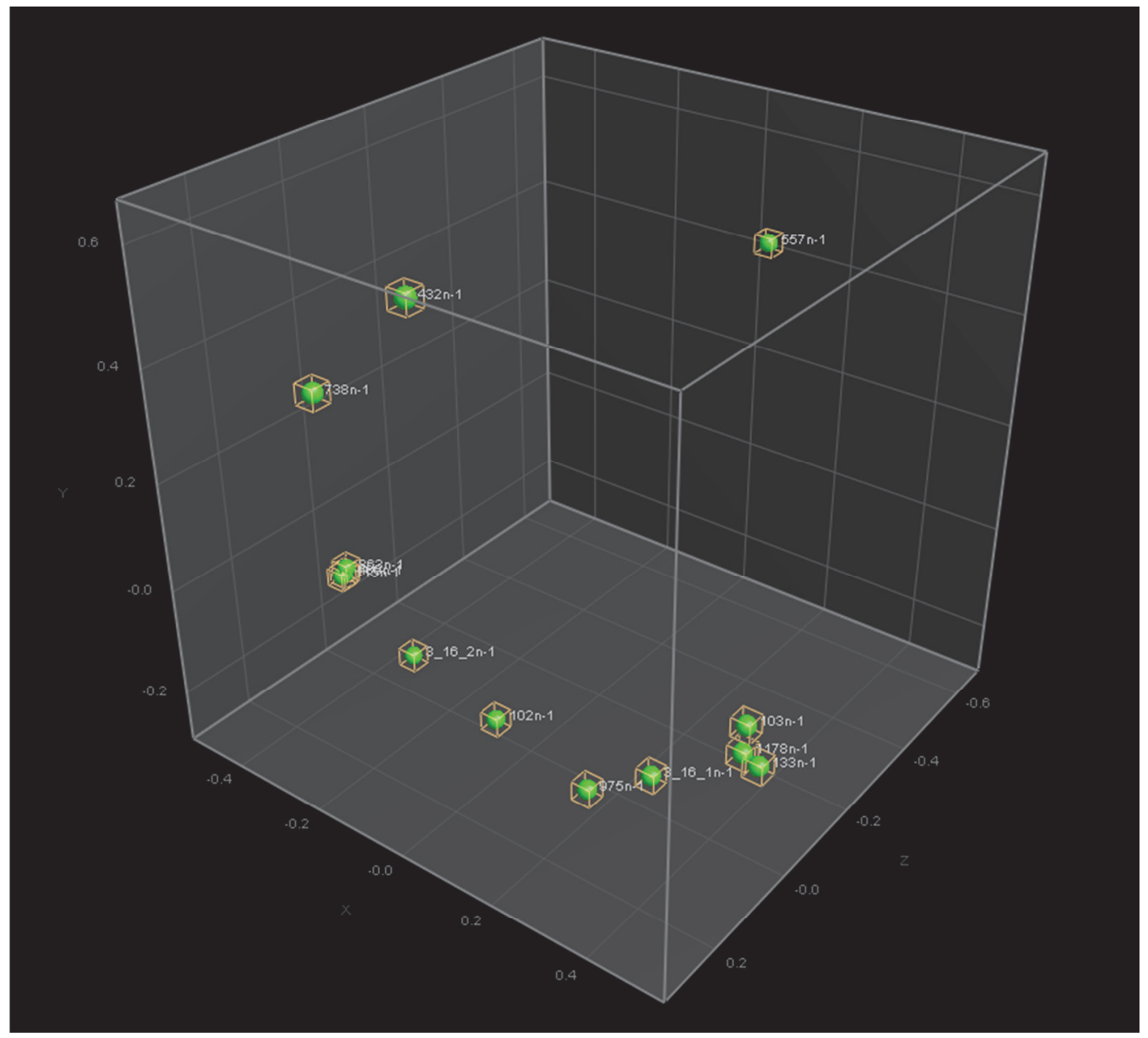

Rys. 4. Analiza MDS. Skalowanie wielowymiarowe profili mas (MS) uzyskanych analizą MALDITOF, określające podobieństwa i różnice pomiędzy badanymi szczepami Lactobacillus

Fig. 4. MDS analysis. Multidimensional scaling of mass spectra (MS) profiles obtained using MALDITOF analysis and showing similarities and differences between analysed Lactobacillus strains

W analizie klastrów zidentyfikowanych na podstawie sekwencji genów $16 \mathrm{~S}$ rDNA i pheS zaobserwowano, że gen pheS w badanych szczepach charakteryzował się wysokim stopniem konserwatywności i niskim potencjałem różnicującym. Analizą sekwencji pheS dowiedziono, że bakterie z rodzaju Lactobacillus mają duże pokrewieństwo tego genu, co może wskazywać na niewielkie możliwości jego zastosowania jako wiarygodnego i czułego narzędzia do różnicowania. Tylko w przypadku 3 szczepów w obu metodach uzyskano ten sam wynik identyfikacji (L. plantarum 1178, L. plantarum 867 i L. brevis 557). Spośród metod molekularnych analiza genu $16 S$ rDNA umożliwiła uwidocznienie większej różnorodności badanych szczepów w porównaniu 
$\mathrm{z}$ analizą pheS (tab. 2), co potwierdzono również w analizie różnorodności nukleotydowej badanych sekwencji, w której współczynnik $\pi$ był wyższy dla genu $16 S$ rDNA $(0,86)$ niż dla genu pheS $(0,16)$. Po przeprowadzeniu analizy $16 S \mathrm{r}$ DNA zidentyfikowano 4 szczepy $L$. brevis (DSM 6235, 557, 489, 3/16/1), po 2 szczepy L. plantarum $(1178,863)$, L. rhamnosus $(975,115)$, L. backii $(102,103)$ i po jednym - L. curvatus (432) i L. rossiae (738). W analizie genu pheS zróżnicowanie szczepów było znacznie mniejsze. Otrzymano 8 szczepów L. plantarum (DSM 6235, 1178, 975, 863, 738, 489, 133, 3/16/1) i 2 szczepy L. brevis $(557,432)$. W przypadku 2 szczepów scharakteryzowanych jako L. backii, w analizie $16 S$ rDNA nie udało się uzyskać sekwencji pheS. Stwierdzono, że badaniem sekwencji $16 S$ rDNA uzyskuje się większe możliwości różnicujące.

W identyfikacji metodą MALDI-TOF MS, w obu analizach, uzyskano taki sam wynik dla 10 z 12 szczepów: 7 - L. brevis (DSM 6235, 102, 103, 489, 863, 975, 3/16/1), 2 - L. plantarum $(1178,133)$ i 1 - L. curvatus. W przypadku szczepów 432 i 738 otrzymano różną identyfikację.

Identyfikacja wybranych bakterii kwasu mlekowego metodami molekularnymi i porównanie ich z metodą MALDI-TOF MS doprowadziły do wniosku, że wyniki wszystkich metod pokrywały się tylko w przypadku jednego szczepu L. plantarum 1178. Dla porównania taką samą identyfikację z użyciem genu $16 S$ rDNA i MALDITOF MS uzyskano dla 5 szczepów, w tym 3 szczepów L. brevis (DSM 6235, 3/16/1 i 489), jednego szczepu L. plantarum 1178 i szczepu $F$. rossiae 738, ale w przypadku MALDI-TOF MS tylko z pierwszej analizy. W wyniku porównania metod z wykorzystaniem sekwencjonowania genu pheS i MALDI-TOF MS uzyskano taki sam wynik (w obu metodach) w przypadku szczepów 1178 i 133 i zidentyfikowano je jako $L$. plantarum, a w przypadku pierwszej analizy MALDI-TOF MS scharakteryzowano szczep 432 jako L. brevis.

Jak podają Naser i wsp. [8], analiza różnicowania blisko spokrewnionych bakterii z rodzaju Lactobacillus na podstawie genu pheS stanowi wiarygodną, alternatywną metodę dla genu $16 S$ rDNA. W badaniach własnych wykazano jednak, że identyfikacja szczepów LAB z zastosowaniem sekwencjonowania genu pheS była mało zróżnicowana, a w analizie porównawczej odnotowano wysoki poziom homologii tego genu w badanych szczepach (98\%). Podobne wyniki uzyskali wcześniej Naser i wsp. [7] w badaniach nad identyfikacją bakterii z gatunku Enterococcus. Zaobserwowali oni, że gen pheS miał wysoki stopień homogeniczności wśród badanych szczepów. Podobieństwo sekwencji genu pheS w szczepach Enterococcus wynosiło $97 \%$, co wskazywało na niską moc dyskryminacyjną tego genu przy zastosowaniu do różnicowania wewnątrzgatunkowego. Sanches-Juanes i wsp. [10] stwierdzili, że identyfikacja bakterii kwasu mlekowego z użyciem genu pheS oraz metoda MALDI-TOF MS są wiarygodnymi technikami identyfikacji tych bakterii i mają dużą siłę dyskryminacyjną. Obie 
Tabela 2. Wyniki identyfikacji bakterii kwasu mlekowego z zastosowaniem metod sekwencjonowania genu $16 S$ rDNA, genu pheS i techniki MALDI-TOF MS

Table 2. Identification results of lactic acid bacteria using $16 S$ rDNA and pheS gene sequencing methods and MALDI-TOF MS technique

\begin{tabular}{|c|c|c|c|c|}
\hline \multirow{2}{*}{$\begin{array}{l}\text { Szczep } \\
\text { Strain }\end{array}$} & \multirow{2}{*}{$\begin{array}{l}\text { Analiza } 16 S \text { rDNA } \\
16 S \text { rDNA analysis }\end{array}$} & \multirow{2}{*}{$\begin{array}{l}\text { Analiza genu pheS } \\
\text { Gene } p h e S \text { analysis }\end{array}$} & \multicolumn{2}{|c|}{$\begin{array}{l}\text { Analiza MALDI-TOF MS } \\
\text { MALDI-TOF MS analysis }\end{array}$} \\
\hline & & & I & II \\
\hline 1178 & $\begin{array}{c}\text { Lactiplantibacillus } \\
\text { plantarum }\end{array}$ & $\begin{array}{c}\text { Lactiplantibacillus } \\
\text { plantarum }\end{array}$ & $\begin{array}{c}\text { Lactiplantibacillus } \\
\text { plantarum }\end{array}$ & $\begin{array}{c}\text { Lactiplantibacillus } \\
\text { plantarum }\end{array}$ \\
\hline 975 & $\begin{array}{c}\text { Lacticaseibacillus } \\
\text { rhamnosus }\end{array}$ & $\begin{array}{c}\text { Lactiplantibacillus } \\
\text { plantarum }\end{array}$ & $\begin{array}{c}\text { Levitlactobacillus } \\
\text { brevis }\end{array}$ & $\begin{array}{c}\text { Levitlactobacillus } \\
\text { brevis }\end{array}$ \\
\hline 863 & $\begin{array}{c}\text { Lactiplantibacillus } \\
\text { plantarum }\end{array}$ & $\begin{array}{c}\text { Lactiplantibacillus } \\
\text { plantarum }\end{array}$ & $\begin{array}{c}\text { Levitlactobacillus } \\
\text { brevis }\end{array}$ & $\begin{array}{c}\text { Levitlactobacillus } \\
\text { brevis }\end{array}$ \\
\hline $\begin{array}{l}\text { DSM } \\
6235 \\
\end{array}$ & $\begin{array}{c}\text { Levitlactobacillus } \\
\text { brevis }\end{array}$ & $\begin{array}{c}\text { Lactiplantibacillus } \\
\text { plantarum }\end{array}$ & $\begin{array}{c}\text { Levitlactobacillus } \\
\text { brevis }\end{array}$ & $\begin{array}{c}\text { Levitlactobacillus } \\
\text { brevis }\end{array}$ \\
\hline 102 & $\begin{array}{c}\text { Levitlactobacillus } \\
\text { backii }\end{array}$ & NR & $\begin{array}{c}\text { Levitlactobacillus } \\
\text { brevis }\end{array}$ & $\begin{array}{c}\text { Levitlactobacillus } \\
\text { brevis } \\
\end{array}$ \\
\hline 103 & $\begin{array}{c}\text { Levitlactobacillus } \\
\text { backii }\end{array}$ & NR & $\begin{array}{c}\text { Levitlactobacillus } \\
\text { brevis }\end{array}$ & $\begin{array}{c}\text { Levitlactobacillus } \\
\text { brevis }\end{array}$ \\
\hline 133 & $\begin{array}{c}\text { Lacticaseibacillus } \\
\text { rhamnosus }\end{array}$ & $\begin{array}{c}\text { Lactiplantibacillus } \\
\text { plantarum }\end{array}$ & $\begin{array}{c}\text { Lactiplantibacillus } \\
\text { plantarum }\end{array}$ & $\begin{array}{c}\text { Lactiplantibacillus } \\
\text { plantarum }\end{array}$ \\
\hline $3 / 16 / 1$ & $\begin{array}{c}\text { Levitlactobacillus } \\
\text { brevis }\end{array}$ & $\begin{array}{c}\text { Lactiplantibacillus } \\
\text { plantarum }\end{array}$ & $\begin{array}{c}\text { Levitlactobacillus } \\
\text { brevis }\end{array}$ & $\begin{array}{c}\text { Levitlactobacillus } \\
\text { brevis }\end{array}$ \\
\hline 432 & $\begin{array}{c}\text { Latilactobacillus } \\
\text { curvatus }\end{array}$ & $\begin{array}{c}\text { Levitlactobacillus } \\
\text { brevis }\end{array}$ & $\begin{array}{c}\text { Levitlactobacillus } \\
\text { brevis }\end{array}$ & $\begin{array}{c}\text { Lacticaseibacillus } \\
\text { rhamnosus }\end{array}$ \\
\hline 489 & $\begin{array}{c}\text { Levitlactobacillus } \\
\text { brevis }\end{array}$ & $\begin{array}{c}\text { Lactiplantibacillus } \\
\text { plantarum }\end{array}$ & $\begin{array}{c}\text { Levitlactobacillus } \\
\text { brevis }\end{array}$ & $\begin{array}{c}\text { Levitlactobacillus } \\
\text { brevis }\end{array}$ \\
\hline 557 & $\begin{array}{c}\text { Levitlactobacillus } \\
\text { brevis }\end{array}$ & $\begin{array}{c}\text { Levitlactobacillus } \\
\text { brevis }\end{array}$ & $\begin{array}{c}\text { Latilactobacillus } \\
\text { curvatus }\end{array}$ & $\begin{array}{c}\text { Latilactobacillus. } \\
\text { curvatus }\end{array}$ \\
\hline 738 & $\begin{array}{c}\text { Furfurilactobacillus } \\
\text { rossiae }\end{array}$ & $\begin{array}{c}\text { Lactiplantibacillus } \\
\text { plantarum }\end{array}$ & $\begin{array}{c}\text { Furfurilactobacillus } \\
\text { rossiae }\end{array}$ & $\begin{array}{c}\text { Levitlactobacillus } \\
\text { brevis }\end{array}$ \\
\hline
\end{tabular}

Objaśnienie / Explanatory note:

NR - brak wyników / no results.

techniki umożliwiły autorom przypisanie bakterii do właściwego rodzaju i gatunku. W przypadku badań własnych takie same wyniki otrzymano dla dwóch z 12 szczepów zidentyfikowanych jako L. plantarum $(1178,133)$, z czego tylko jeden szczep 1178 został potwierdzony jako L. plantarum również w analizie $16 S$ rDNA oraz dla szczepu $432 \mathrm{w}$ jednej analizie MALDI-TOF MS, w której został on przypisany do L. brevis. W identyfikacji bakterii metodą MALDI-TOF MS kluczowa jest zasobność bazy danych urządzenia w widma masowe, gdyż w dużej mierze od niej zależy właściwe scharakteryzowanie mikroorganizmu. Porównanie wyników identyfikacji przy użyciu dwóch urządzeń, ale zawierających różne biblioteki danych, dowodzi, że w niektórych przypadkach identyfikacja może się różnić (szczep 432, 738). 


\section{Wnioski}

1. Przy doborze metod różnicujących i identyfikujących szczepy bakterii kwasu mlekowego stwierdzono, że sekwencjonowanie genu $16 S$ rDNA umożliwiło większe zróżnicowanie bakterii w porównaniu z analizą genu pheS, który charakteryzował się większą homologią, a przez to miał znacznie mniejszy potencjał różnicujący.

2. Wartość współczynnika różnorodności nukleotydowej $(\pi)$ sekwencji potwierdziła większą homologię w obrębie genu pheS w stosunku do genu $16 \mathrm{~S}$ rDNA.

3. Analizą nukleotydową badanych sekwencji nie wykazano korelacji $\mathrm{z}$ analizami filogenetycznymi.

4. Stwierdzono, że możliwości dyskryminacyjne MALDI-TOF MS są porównywalne do innych stosowanych procedur identyfikacyjnych. Metoda ta nadaje się do rutynowego stosowania dzięki szybkości, precyzji i prostocie przygotowania próbki.

5. Uznano, że przy identyfikacji bakterii metodą MALDI-TOF MS duże znaczenie miała biblioteka referencyjnych widm masowych, do której analizowane szczepy były porównywane.

\section{Literatura}

[1] Akimowicz M., Bucka-Kolendo J.: MALDI-TOF MS - application in food microbiology. Acta Biochimica Polonica, 2020, (3) 67, 327-332.

[2] Berg G., Rybakova D., Fischer D., Cernava T., Verges M.-C.C., Charles T., Chen X., Cocolin L., Eversole K., Corral G.H., Kazou M., Kinkel L., Lange L., Lima N., Loy A., Macklin J.A., Maguin E., Mauchline T., McClure R., Mitter B., Rayan M., Sarand I., Smidt H., Schelkle B., Roume H., Kira G.S., Selvin J., de Souza R.S.C., van Overbeek L., Singh B.K., Wagner M., Walsh M., Sessitsch A., Schloter M.: Microbiome definition re-visited: Old concepts and new challenges. Microbiome, 2020, 8, \#103.

[3] Bucka-Kolendo J., Sokołowska B., Winiarczyk S.: Influence of high hydrostatic pressure on the identification of Lactobacillus by MALDI-TOF MS - Preliminary study. Microorganisms, 2020, 8 (6), \#813.

[4] Chao S.-H., Kudo Y., Tsai Y.-Ch., Watanabe K.: Lactobacillus futsaii sp. nov., isolated from fu-tsai and suan-tsai, traditional Taiwanese fermented mustard products. Int. J. Syst. Evol. Microbiol., 2012, 62 (3), 489-494.

[5] Foschi C., Laghi L., Parolin C., Giordani B., Compri M., Cevenini R., Margangoni A., Vitali B.: Novel approaches for the taxonomic and metabolic characterization of lactobacilli: Integration of 16S rRNA gene sequencing with MALDI-TOF MS and H-NMR. PLoS ONE, 2017, 12(2), \# 0172483.

[6] Kumar S., Stecher G., Li M., Knyaz C., Tamura K.: MEGA X: Molecular Evolutionary Genetics Analysis across computing platforms. Mol. Biol. Evol., 2018, 35, 1547-1549.

[7] Naser S., Thompson F., Hoste B., Gevers D., Dawyndt P., Vancanneyt M., Swings J.: Application of multilocus sequences analysis (MLSA) for rapid identification of Enterococcus species based on rpoA and pheS genes. Microbiology, 2005, 151, 2141-2150. 
[8] Naser S., Dawyndt P., Hoste B., Gevers D., Vandemeulebroecke K., Cleenwerck I., Vancanneyt M., Swings J.: Identification of lactobacilli by pheS and rpoA gene sequence analyses. Int. J. Syst. Evol. Microbiol., 2007, 57, 2777-2789.

[9] PN-ISO 15214:2002. Mikrobiologia żywności i pasz. Horyzontalna metoda oznaczania liczby mezofilnych bakterii fermentacji mlekowej. Metoda płytkowa w temperaturze 30 stopni C.

[10] Sánchez-Juanes F., Teixeira-Martín V., González-Buitrago J.M., Velázquez E., Flores-Félix J.D.: Identification of species and subspecies of lactic acid bacteria present in Spanish cheeses type "Torta" by MALDI-TOF MS and pheS gene analyses. Microorganisms, 2020, 8(2), \#301.

[11] Sharma A., Lee S., Park Y.-S.: Molecular typing tools for identification and characterizing lactic acid bacteria: A review. Food Sci. Biotechnol., 2020, 29(10), 1301-1318.

[12] Stackebrandt E., Fredriksen W., Garrity G.M., Grimont P.A.D., Kampfer P., Maidem M.C.J., Nesme X., Rossello-Mora R., Swings J., Truper H.G., Vauterin L., Ward A.C., Whitman W.B.: Report of the ad hoc committee for the re-evaluation of the species definition in bacteriology. Int. J. Syst. Evol. Microbiol., 2002, 52, 1043-1047.

[13] Stefańska I., Stecka K.: Postępy w identyfikacji i różnicowaniu bakterii fermentacji mlekowej. Część I. Postępy Nauki i Technologii Przemysłu Rolno-Spożywczego, 2012, 67 (3), 35-51.

[14] Stefańska I., Stecka K.: Postępy w identyfikacji i różnicowaniu bakterii fermentacji mlekowej. Część II. Postępy Nauki i Technologii Przemysłu Rolno-Spożywczego, 2012, 67 (4), 49-66.

[15] Zheng J., Wittouck S., Salvetti E., Franz C.M.A.P., Harris H.M.B., Mattarelli P., O'Tolle P.W., Pot W., Vandamme P., Walter J., Watanabe K., Wuyts S., Felis G.E., Ganzle M.G., Lebeer S.: A taxonomic note on the genus Lactobacillus: Description on 23 novel genera, emended description of the genus Lactobacillus Beijerinck 1901, and union of Lactobacillaceae and Leuconostocaceae. Int. J. Syst. Evol. Microbiol., 2020, 70, 2782-2858.

\title{
COMPARISON OF LACTOBACILLUS IDENTIFICATION METHODS
}

\author{
S u m m a ry
}

Lactic acid bacteria (LAB) are widely used in various sectors of food industry, in biotechnology and in medicine, therefore it is very important to properly identify them and to correctly assess their intra-species differentiation. The selection of appropriate molecular analysis techniques should take into account the high accuracy, repeatability and typability of the method.

The objective of the research study was to assess the possibility of differentiating 12 Lactobacillus strains with the use of techniques commonly applied in laboratories: the sequencing of the $16 \mathrm{~S}$ rDNA gene, pheS gene and MALDI-TOF MS. Based on the analysis results obtained, it was found that in the tested strains the pheS gene was characterised by a high level of homology (98\%) and a low discriminant power. In the two independent MALDI-TOF MS analyses the same result was obtained for 10 strains: seven - L. brevis (DSM 6235, 102, 103, 489, 863, 975, 3/16/1), two - L. plantarum $(1178,133)$ and one L. curvatus 557. After the performed sequencing analysis of the $16 \mathrm{~S}$ rDNA gene the findings were confirmed only in the case of five (DSM 6235, 3/16/1 and 489) of the twelve strains tested. The comparison of the results obtained made it possible to conclude that as for the selected LAB strains the highest differentiating value had the analysis based on the sequencing of the $16 \mathrm{~S}$ rDNA gene.

Key words: lactic acid bacteria, LAB, gene $16 \mathrm{~S}$ rDNA, gene pheS, MALDI-TOF MS 